\title{
Komunikasi efektif komunitas rumah baca (rbk) dalam meningkatkan minat baca pada anak-anak di dusun Kanoman
}

\author{
Aniendhita Paramitha ${ }^{\mathrm{a}, 1, *}$ \\ ${ }^{a}$ Public Relation Community Ahmad Dahlan \\ ${ }^{1}$ Aniendhita@comm.uad.ac.id*; \\ * corresponding author
}

Article history

Received 30-06-2020

Revised 02-07-2020

Accepted 03-07-2020

Keywords

Komunikasi efektif

Komunitas Rumah Baca (RBK)

Minat Baca

\begin{abstract}
Penelitian ini dilakukan dengan dilatar belakangi bahwa minat baca anak-anak di Dusun Kanoman masih rendah. Keberadaan Komunitas Rumah Baca (RBK) sendiri juga di katakan belum berjalan secara efektif. Hal ini dikarenakan Komunitas Rumah Baca (RBK) belum lama berpindah di Dusun Kanoman, volunter yang over load pekerjaan, dan sebagian besar tidak bisa berbahasa Jawa. Tujuan dari penelitian ini adalah untuk mengetahui bagaimana komunikasi efektif Komunitas Rumah Baca (RBK) dalam meningkatkan minat baca pada anak-anak di Dusun Kanoman. Jenis penelitian ini menggunakan metode penelitian kualitatif. Teknik pengumpulan data didapatkan dari hasil wawancara, observasi, dan dokumentasi. Teknik analisis data yang digunakan dalam penelitian ini ialah menggunakan model analisis interaktif Miles dan Huberman dengan pendekatan deskriptif analisis. Hasil penelitian menunjukkan bahwa Komunitas Rumah Baca (RBK) dikatakan mampu meningkatkan minat baca anak-anak di Dusun Kanoman. Hal ini terbukti bahwa anak-anak mulai berkeinginan untuk membaca dan meminjam buku di komunitas. Komunitas juga menerapkan prisip komunikasi efektif yang disingkat REACH. Ada hambatan yang dialami dari pihak komunitas maupun anak-anak, namun hambatan itu dapat diatasi.
\end{abstract}

\section{Introduction}

Perlu diketahui bahwasanya minat baca masyarakat Indonesia, khususnya anak-anak masih sangat rendah. Menurut detik.com menyatakan data hasil penelitian yang dilakukan oleh Program For International Student Assessment (PISA) tahun 2015, Indonesia berada pada ranking 62 dari 70 negara yang disurvei. Tak hanya itu saja, Indonesia juga berada di urutan 60 dari 61 negara yang disurvei oleh World's Most Literate Nations yang diumumkan pada Maret 2016 (Bauer \& Plehn, 2019). Ada beberapa faktor yang menyebabkan rendahnya minat baca pada anak-anak yaitu masih sulitnya akses terhadap buku karena jumlah toko buku yang terbatas, sedikitnya perpustakaan yang berada disuatu wilayah, harga buku yang tinggi, daya beli yang rendah tidak adanya penanaman kebiasaan membaca sejak dini, tidak memadai dan tidak sesuai kebutuhan buku sehingga masih sulit mengakses informasi, banyaknya jenis hiburan, play station, tayangan TV, taman rekreasi, mal, supermarket, dan lain-lain. Ditambah lagi dengan kehadiran internet.

Untuk itu diperlukan sebuah komunitas penggerak literasi yang memiliki peran penting dalam meliterasi masyarakat. Untuk dapat mewujudkannya diperlukan komunikasi yang efektif guna memberikan kemudahan dalam memahami pesan yang disampaikan. Adapun komunitas literasi 
yang dijadikan bahan penelitian yaitu Komunitas Rumah Baca (RBK) (Schotter, Pollatsek, \& Rayner, 2016).

Di ketahui bahwasanya anak-anak di Dusun Kanoman pada awalnya sangat nakal dan susah untuk diatur. Minat baca anak-anak pun rendah. Keberadaan Komunitas Rumah Baca (RBK) sendiri juga di katakan belum efektif karena belum lama berpindah di Dusun Kanoman. Hal lain yang menjadi kendala yaitu kebanyakan volunteer yang over load pekerjaan sehingga program untuk anak-anak masih belum berjalan dengan baik.Komunitas Rumah Baca (RBK) sendiri berbeda dengan komunitas lainnya. Komunitas ini membuat perpustakaan yang buka 24 jam. Tak hanya itu saja komunitas ini pun memudahkan anak-anak untuk meminjam buku dengan tidak mewajibkan tanda identitas diri seperti Kartu Tanda Mahasiswa (KTM), Kartu Tanda Penduduk (KTP) atau kartu pelajar dan sejenisnya bagi yang ingin memanfaatkan buku-buku di dalamnya. Komunitas juga bekerjasama dengan berbagai komunitas lain, jejaring komunitas, sekolah, maupun personal yang dimiliki. Hal itu pulalah yang membuat komunitas ini mandiri tanpa harus meminta dana dari pemerintah (Muniz \& O’Guinn, 2001).

\section{Theorotocal Framework}

\section{1) Komunikasi}

Menurut Lasswell mendefinisikan komunikasi sebagai proses penyampaian pesan dari seorang komunikator pada komunikan melalui sebuah media yang pada akhirnya akan menimbulkan efek tertentu (Thayer, 2019).

\section{a) Komunikasi Efektif}

Menurut Rochmah, komunikasi efektif adalah komunikasi yang mampu menghasilkan perubahan sikap (attitude change) pihak-pihak yang terlibat dalam komunikasi. Prinsip dasar berkomunikasi secara efektif adalah REACH (Respect, Empathy, Audible,Clarity, Humble ). Menurut Effendy, AIDDA ialah gabungan dari kata Attention (perhatian), Interest (minat), Desire (hasrat), Decision (keputusan), dan Action (tindakan/ kegiatan) (Communication, 2012).

\section{b) Komunitas}

Menurut Yudistira Grana, komunitas ialah sekelompok manusia yang menempati suatu wilayah geografis, yang di dalamnya terlibat aktivitas ekonomi, politik, serta membentuk suatu satuan sosial yang memiliki nilai-nilai tertentu dan rasa kebersamaan. (Underwood, 2018)

\section{Method}

Dalam penelitian ini peneliti menggunkan metode penelitian kualitatif. Penelitian ini dilakukan di Komunitas Rumah Baca (RBK) di Dusun Kanoman RT.04 / RW.05, Area Sawahan, Banyuraden, Gamping, Sleman. Sedangkan objek penelitian adalah komunikasi efektif Komunitas Rumah Baca dalam meningkatkan minat baca pada anak-anak (Sugiyono \& Republik Indonesia, 2010). Penelitian ini dilakukan pada bulan April sampai Juli 2019. Peneliti melakukan observasi secara langsung terhadap objek penelitian yaitu komunikasi efektif Komunitas Rumah Baca, khususnya bagaimana cara meningkatkan minat baca pada anak-anak Dusun Kanoman. Penelitian ini menggunakan wawancara terpimpin. Yang menjadi informan adalah : pendiri Komunitas Rumah Baca, volunteer Komunitas Rumah Baca, anak-anak di Dusun Kanoman, dan orang tua anak-anak di Dusun Kanoman. Teknik dokumentasi yan digunakan berbentuk data-data, catatan, arsip, bahkan foto-foto yang terkait dengan aktivitas dan kegiatan yang diadakan Komunitas Rumah Baca (RBK) untuk meningkatkan minat baca pada anak-anak di Dusun Kanoman. Teknik analisis data yang digunakan menggunakan model analisis interaktif Miles dan Huberman yang meliputi : (1) reduksi data, (2) display / penyajian data, dan (3) mengambil kesimpulan lalu diverivikasi. Pendekatan yang dilakukan dengan pendekatan deskriptif analisis. Dalam penelitian ini, peneliti menggunakan teknik triangulasi (Agusta, 2014).

\section{Results and Discussion}

Komunitas Rumah Baca (RBK) dengan menarik simpatisan warga agar anak-anak mereka datang ke sana. Hal itu memberikan respon positif dari orang tua anak-anak. Para volunter 
mendekatkan diri dan memberitahu anak-anak untuk menginformasikan kepada anak yang lainnya untuk datang ke komunitas.

1) Interest (Minat)

Komunitas memberikan berbagai macam kegiatan untuk memberikan edukasi kepada anak-anak. Komunitas Rumah Baca (RBK) mempunyai program khusus anak-anak yang diberi nama RBK for kids. Program tersebut membuat anak-anak tertarik.

2) Desire (Keinginan)

Pada tahap ini Komunitas Rumah Baca (RBK) membuka kesempatan bahwa semua buku boleh dipinjam tanpa syarat dan buka selama 24 jam.

3) Decision (Keputusan)

Komunitas memiliki 2 strategi untuk membuat anak-anak dekat dengan buku yaitu strategi yang sifatnya alamiah dan non alamiah. Anak-anak Dusun Kanoman ini dikenalkan lebih dalam tentang Komunitas Rumah Baca (RBK) dengan cara diberikan fasilitas yang menunjang. Ada perubahan yang terjadi pada diri anak-anak setelah mereka diberikan fasilitas yang menunjang di Komunitas Rumah Baca (RBK).

\section{4) Action (Tindakan / Kegiatan)}

Komunitas yang tiba-tiba muncul di dusunnya membuat anak-anak kaget karena tidak memilik tradisi yang kuat tentang membaca. Namun akses bacaan yang mudah dirasa membuat anak-anak tertarik untuk melihat-lihat buku yang ada. Untuk itu dibutuhkan seorang fasilitator untuk mendampingi mereka. Bahan bacaan yang beragam membuat mereka bekeinginan untuk membaca dan meminjam buku di Komunitas Rumah Baca (RBK).

5) Hambatan Komunikasi

Hambatan yang dialami oleh Komunitas Rumah Baca (RBK) disebabkan oleh beberapa faktor. Faktor tersebut yaitu budaya anak-anak yang tidak kuat dalam membaca, duk ungan orang tua yang ala kadarnya, volunter yang over load pekerjaan dan tidak bisa berbahasa Jawa. Komunitas Rumah Baca (RBK) juga memberikan motivasi-motivasi kepada anak-anak untuk gemar membaca. Anak-anak mulai mengetahui komunitas yang baru ada di dusunnya. Tak hanya itu, orang tua pun merasa senang dan gembira dengan hadirnya komunitas bisa membantu warga serta anak-anak dapat menambah ilmu baca dan tulis.

a) Interest (Minat)

Program RBK for kids berhasil membuat anak-anak ikut berpartisipasi dalam kegiatan yang dilakukan komunitas.

\section{b) Desire (Keinginan)}

Komunitas membuka kesempatan akses bagi siapa saja dengan cara buka selama 24 jam. Buku yang ada di Komunitas Rumah Baca juga bisa dipinjam tanpa adanya syarat apapun. Hal itu membuat anak-anak mulai tertarik untuk datang karena buku-buku yang ada di komunitas sangat beragam dan menarik.

\section{c) Decision (Keputusan)}

Komunitas Rumah Baca (RBK) membuat perubahan pada diri anak-anak. Perubahan yang terjadi pada setiap anak-anak beda-beda. Ada juga yang perubahannya biasa-biasa saja karena sudah jarang datang ke komunitas.

\section{d) Action (Tindakan / Kegiatan)}

Komunitas mendampingi anak-anak untuk belajar karena mereka belum terbiasa untuk membaca. Namun dengan akses bacaan yang mudah membuat anak-anak senang dan tertarik untuk membaca.

\section{e) Respect (Menghargai)}

Komunitas mendekatkan diri dengan anak-anak dengan cara menyapa mereka terlebih dahulu.

f) Empathy (Empati)

Komunitas mengajarkan anak-anak untuk belajar membaca juga mendampingi anak-anak ketika mereka belajar. Komunitas tidak memaksa anak-anak ketika datang harus membaca. 
g) Audible (Memahami)

Para volunter mampu memahami setiap karakter anak-anak yang berbeda-beda dengan cara berlaku adil kepada semua anak-anak.

h) Clarity (Jelas)

Anak-anak merasa nyaman dengan para volunter karena mereka dibebaskan ketika datang ke sana. Mereka sudah menganggap komunitas sebagai rumah kedua mereka..

i) Humble (Rendah Hati)

Komunitas memberikan dukungan dan motivasi kepada anak-anak untuk gemar membaca.

6) Faktor Komunikasi Efektif

a) Kepercayaan (Credibilyty)

Anak-anak dan volunter saling percaya, terbukti dari komunitas mampu mengajak anak-anak datang dan mengikuti apa yang diberikan.

b) Perhubungan Pertalian (Contex)

Volunter mampu memahami setiap anak-anak dan menjadikan mereka sejajar.

c) Kepuasan (Conten)

Anak-anak belum merasa puas saat berkomunikasi dengan volunter karena mereka tidak paham yang disampaikan dan memilih diam.

d) Kejelasan (Clarity)

Volunter berusaha menyampaikan pesan dengan bahasa yang dipahami yaitu Bahasa Indonesia, namun ada juga yang tidak paham.

e) Kesinambungan dan Konsistensi (Capability and Consistency)

Volunter selalu mengajak anak-anak berbincang-bincang saat datang.

7) Kemampuan Pihak Penerima Berita (Capability of Audience)

Volunter menggunakan bahasa yang campur aduk saat berbicara dikarenakan kebanyakkan tidak bisa Berbahasa Jawa.

a) Saluran Pengiriman Berita (Chanels of Distributor)

Komunitas menggunakan saluran komunikasi tatap muka dengan anak-anak maupun orang tua anak-anak.

8) Hambatan Komunikasi Efektif

a) Hambatan Proses

Hambatan Pengirim : terjadi ketika para vounter mengajarkan kepada mereka terlalu kaku dan menurut anak-anak terlalu membosankan. Hambatan Encoding : terjadi ketika para vounter mengajak anak-anak belajar di waktu yang tidak tepat. Hambatan Media : terjadi ketika para volunter menggunakan bahasa yang campur-campur saat berbicara. Hambatan Decoding : terjadi ketika anak-anak tidak memahami bahasa yang digunakan oleh para volunter. Hambatan Penerima : terjadi ketika anak-anak merasa kesusahan dalam memahami pesan yang disampaikan volunter. Hambatan Umpan Balik : terjadi ketika ada anak yang tidak bertanya ketika mereka mengalami kendala saat vounter menyampaikan pesan.

b) Hambatan Fisik

Terjadi karena para volunter yang over load pekerjaan sehingga membuat kurang intensif dalam mendampingi anak-anak.

c) Hambatan Semantik 
Terjadi karena kebanyakan volunter tidak bisa berbahasa Jawa, sehingga anak-anak menjadi kesulitan memahami yang disampaikan. Bahasa yang campur-campur juga dikeluhkan oleh anakanak.

\section{d) Hambatan Psikologi}

Bidang Pengalaman : terjadi karena anak-anak tidak memiliki tradisi yang kuat untuk membaca serta dukungan dari orang tua ala kadarnya. Penyaringan : terjadi ketika ada salah satu anak yang terlihat masih marah pada salah satu volunter karena suatu hal dan membuat ia tidak mau bertemu sehingga memilih untuk menghindar. Jarak Psikologis : terjadi karena kondisi anak-anak yang berubah-ubah dan danya persaingan antar anak-anak yang ingin mendominasi yang berdampak pada anak-anak lainnya tidak datang kembali.

\section{e) Dukungan untuk Anak-anak}

Komunitas Rumah Baca (RBK) memberikan motivasi-motivasi kepada anak-anak untuk gemar membaca. Dengan cara mengetahui apa yang di senangi anak-anak sehingga komunitas menyelipkan poin-poin yang penting ke dalamnya.

\section{Conclusion}

Komunitas memberikan sosialisasi kepada warga dan volunter pun juga melakukan pendekatan kepada anak-anak. Komunitas memberikan berbagai kegiatan sehingga membuat anak-anak mulai ikut berpartisipasi. Komunitas membuat anak-anak tergugah dengan adanya buku-buku yang menarik dan beragam, akses yang mudah, dan berbagai fasilitas yang ada. Anak-anak mulai aktif ikut kegiatan-kegiatan untuk mendekatkan pada buku. Komunitas melakukan pendampingan saat belajar dan memberikan berbagai macam program yang bersentuhan langsung dengan buku sehingga membuat mereka berkeinginan untuk membaca dan meminjam buku. Komunitas pun sudah menggunakan prinsip komunikasi REACH, meskipun masih ada hambatan yang dialami. Komunitas juga memberikan dukungan untuk anak-anak.

\section{References}

Agusta, I. (2014). Teknik Pengumpulan dan Analisis Data Kualitatif. Jurnal Studi Komunikasi Dan Media.

Bauer, M., \& Plehn, T. (2019). Further Reading. In Lecture Notes in Physics. https://doi.org/10.1007/978-3030-16234-4_8

Communication, C. (2012). Handbook of Risk. In Communication. https://doi.org/10.1007/978-94-007-14335

Muniz, A. M., \& O'Guinn, T. C. (2001). Brand Community. Journal of Consumer Research. https://doi.org/10.1086/319618

Schotter, E. R., Pollatsek, A., \& Rayner, K. (2016). Reading. In The Curated Reference Collection in Neuroscience and Biobehavioral Psychology. https://doi.org/10.1016/B978-0-12-809324-5.01895-2

Sugiyono, \& Republik Indonesia. Metode Penelitian Kuantitatif \& kualitatif. , Journal of Experimental Psychology: General § (2010).

Thayer, L. (2019). Communication. In Evolution-Revolution: Patterns of Development in Nature Society, Man and Knowledge. https://doi.org/10.4324/9780429325359-7

Underwood, A. J. (2018). Community. In Encyclopedia of Ecology. https://doi.org/10.1016/B978-0-44463768-0.00473-X 